\title{
Reality and Justice: Seamus Heaney's The Cure at Troy
}

\author{
Marilynn Richtarik \\ Georgia State University, Atlanta, USA
}

Copyright (c) 2018 by Marilynn Richtarik. This text may be archived and redistributed both in electronic form and in hard copy, provided that the author and journal are properly cited and no fee is charged for access.

\begin{abstract}
In his Field Day play The Cure at Troy (1990), Seamus Heaney was responding more directly than has been hitherto recognized to the contemporary political situation in Northern Ireland. This essay examines Heaney's drama in the context of the first tentative steps in what would come to be called the peace process: SDLP leader John Hume's early discussions with Sinn Féin leader Gerry Adams. Through his imaginative use of the Chorus, Heaney sought to encourage the play's original audiences to focus on the future rather than the past, and to believe that something better was possible.
\end{abstract}

Key Words. Seamus Heaney, The Cure at Troy, Peace Process, Northern Ireland, John Hume, Gerry Adams, Field Day Theatre Company.

Resumen. En la obra The Cure at Troy (1990), escrita para la compañía Field Day, Seamus Heaney estaba respondiendo a los acontecimientos de ese momento en Irlanda del Norte de una forma más inmediata de lo que hasta ahora se ha interpretado. En este artículo se examina dicha obra de Heaney con el trasfondo de los primeros y vacilantes pasos de lo que llegaría a ser el proceso de paz, concretamente, las conversaciones que por primera vez mantuvieron el lider del SDLP, John Hume, y el líder del Sinn Féin, Gerry Adams. A través de un uso altamente imaginativo del Coro, Heaney buscó transmitir al público al que originalmente estaba destinada la obra la idea de que había que centrarse en el futuro y no en el pasado, así como que creer en un tiempo mejor era posible.

Palabras clave. Seamus Heaney, The Cure at Troy, el proceso de paz, Irlanda del Norte, John Hume, Gerry Adams, compañía de teatro Field Day.

Academic commentary on Seamus Heaney's Hiberno-English version of Philoctetes, The Cure at Troy, first produced by the Field Day Theatre Company in 1990, has tended to focus on the most Heaneyesque elements of it: how he made Sophocles's text his own and its relationship to the rest of his oeuvre. ${ }^{1}$ The avenue of inquiry I will follow here, however, pursues the question of what made Heaney decide that this relatively obscure Greek drama was appropriate and relevant to the pivotal period in which he was writing his drama and in 
which it would be seen by a diverse cross-section of the population of Ireland, north and south. After all, Heaney insisted (truthfully) that his version of the play was, in essence, conservative - calling it "just my homework for Field Day" and stating that his foremost concern in writing it had been to be faithful to the original while rendering it more accessible to those who would see it on tour (Walsh). So what associations did he expect the play to evoke for contemporary Irish (and especially contemporary Northern Irish) audiences? What personal meaning did it have for Heaney himself? Critics have called attention to the way in which the play's most famous Chorus speeches captured the global sense of political possibility at the time of its première and to their enthusiastic appropriation by politicians of various political stripes, including Mary Robinson, Bill Clinton, and Gerry Adams (who borrowed from Heaney's play for the titles of both the British and the American editions of his personal account of the events leading up to the Good Friday Agreement). ${ }^{2}$ The close relationship between this play and the peace process in Northern Ireland is commonly accepted, but usually this is conceived in abstract terms. In what follows, I wish to put this general insight into concrete terms and to elaborate on a specific local political context that probably influenced Heaney's thinking about and writing of the play.

After reading Brian Friel's Making History for the first time in late January 1988, Seamus Heaney responded from the United States, where he spent spring semesters teaching at Harvard University, with a letter praising the play in both political and aesthetic terms and proudly anticipating that autumn's tour of it by the Field Day Theatre Company. Heaney served on the board of directors of Field Day, which had been founded by Friel and actor Stephen Rea in 1980 and produced, on average, one new Irish play each year in addition to issuing publications aimed at breaking down calcified ways of thinking about Irish identity. At this point, along with his "[c]onviction that I have been at the edge of great events", Heaney confessed to having "an acute sense of my distance, and a feeling that this is a critical time". "I do need to get back closer in", he concluded. ${ }^{3}$ Hindsight makes it even clearer that this was, indeed, a crucial juncture. Less than two weeks earlier, on 11 January 1988, his and Friel's mutual friend John Hume, leader of the constitutional nationalist Social Democratic and Labour Party (SDLP), had met with Gerry Adams, President of Provisional Sinn Féin. Because Sinn Féin refused to condemn the use of force by the Provisional Irish Republican Army in pursuit of their shared republican aims, it had long been treated as a pariah by those who renounced violence in Northern Ireland. Thus, Hume's willingness to talk with Adams represented a notable departure from his party's previous position and provoked, as Adams recalls, "an immediate and generally hostile response from the [British and Irish] governments, the other political parties and sections of the media" (Adams 57).

The chorus of condemnation would no doubt have been louder still had Hume's critics known that, prior to this reported meeting, he had been conversing secretly with Adams for some time already. In May 1986, Hume had received a letter from Father Alec Reid, a priest belonging to the Redemptorist Order based at Clonard Monastery in West Belfast. From the start of the Troubles in 1969, Father Reid declared, he had devoted himself to "the processes of peacemaking". To this end, he was in constant contact with people from all sectors of Northern Irish society - especially, owing to his location, with nationalists (McKeever 113). He had known Adams since the mid-1970s, when he helped negotiate an end to a feud within the republican movement, and he believed the Northern Sinn Féin leadership to be genuinely committed to presenting militant republicans with an "alternative" course to armed struggle of pursuing the goal of a united Ireland (McKeever 23, 115). The gist of Father Reid's proposal to Hume, laid out in his letter, was that "the nationalist parties, North and South, would agree, through dialogue between themselves, to formulate and, then, to co-operate in a common Nationalist policy of aims and methods for resolving the conflict and establishing a just and lasting peace". The theory behind this "alternative method" was that "the creation of a 
powerful, combined political force on the Nationalist side" would prompt the IRA to "respond by ending "the armed struggle" (116). The "crucial exercise in the whole enterprise", Father Reid stressed, "would be ongoing, open-ended dialogue between all the parties concerned": "the representatives of the Church as the initiators and co-ordinators of the discussions, the representatives of the constitutional Nationalist parties as the holders of the main political authority in the situation and the representatives of Sinn Féin as the party directly related to "the armed struggle"" (McKeever 117). Hume had always been a proponent of dialogue, but he would naturally worry that any talks between himself and Adams would be exposed and subjected to misinterpretation by unionists and the British government. Father Reid assured him of absolute confidentiality (McKeever 118), and he allowed himself to be persuaded (Adams 42).

According to Adams's account of the peace process, he and Hume met privately for the first time in September 1986. He describes this encounter as "friendly and constructive", although this did not distract either of them from fundamental differences of opinion (Adams 43). ${ }^{4}$ In the 1985 Anglo-Irish Agreement, the Irish and British governments had affirmed that "any change in the status of Northern Ireland would only come about with the consent of a majority of the people of Northern Ireland" (Bew and Gillespie 187), and Hume pointed to this as evidence that the British government had no interest in managing Northern Ireland's affairs indefinitely and would not stand in the way if unionists could be persuaded to accept the idea of a united Ireland. The very suggestion that the constitutional status of Northern Ireland could change had been enough to provoke a frenzy of unionist reaction, but Adams believed that British lack of interest in Northern Ireland was merely implied in the Agreement and would need to be stated explicitly before militant republicans would take much notice of it. He advocated instead a united nationalist front to pressure the British government to withdraw from the North. Despite their divergent viewpoints, Adams felt immensely encouraged by the fact that the meeting had taken place, emphasizing in his account of it the courage Hume showed in engaging with him at all when the political systems in both Ireland and the United Kingdom, not to mention many members of Hume's own party, demonized Sinn Féin. The two men continued to meet in secret, and to present each other's positions to their respective contacts in an effort to arrive at consensus (Adams 43-44).

As old friends of Hume's, Heaney and Friel were quite possibly aware of the early Hume-Adams encounters as they were taking place. ${ }^{5}$ In any case, their attention would have been riveted on Hume in January 1988, when his private relationship with Adams became a controversial public one. The meeting between the two men in January 1988 had been occasioned by their decision at the end of 1987 to broaden their discussions to include their parties; these party-to-party meetings would begin in March. Before they did, though, Northern Irish people would absorb a series of shocks to rival any during the Troubles. On 6 March, three unarmed IRA members in Gibraltar to plan an attack on British soldiers stationed there were shot dead at pointblank range by British undercover agents. The incident confirmed the opinion of many, especially nationalists, that the government was pursuing a "shoot-to-kill" policy against militant republicans (Durkan 128; Bardon 778). The passions aroused by these killings were compounded ten days later, at the republican funeral for the three dead activists. The police, unusually, stayed clear of the mourners, who were attacked by a loyalist with guns and grenades. Three people were killed and many others wounded, and republicans suspected an especially egregious example of collusion between loyalists and the security forces (Adams 67-70). Three days later, as mourners gathered for the funeral of an IRA activist who was one of those murdered at the cemetery, two British Army corporals drove their car into the funeral procession and could not extricate themselves. One of them brandished a gun and fired a warning shot, and members of the crowd, fearing another attack, pulled them from the car, beat, stripped, and killed them (Bew and Gillespie 213). Father 
Reid, who had worked so hard for so long behind the scenes to get people with opposing views to talk with each other, suddenly attained worldwide notoriety as the priest who rushed to offer last rites to the dying soldiers. Disturbing footage of the incident appeared on television screens internationally, and he lamented that "Our parish is seen as dripping in the blood of the murders" (Bew and Gillespie 213). Adams, more combatively, remembers the outrage republicans felt at commentary that branded the soldiers' killers "savages" and "animals" (Adams 73).

Tensions on all sides were running so high after this terrifying fortnight that even Heaney attracted negative attention to himself at a banquet at which he accepted the Sunday Times Award for Literary Excellence. He regarded the killing of the soldiers as "[b]arbaric IRA stuff, but not my fault, nor the fault of Irish people in general, although the Sunday Times and the British press in general had come out with the usual anti-Irish slabber" and recalls, "I just didn't think I could stand up and receive their award without making clear my attitude to that kind of xenophobia" (O'Driscoll 258). The Boston Globe published an extract from Heaney's speech a few months after he delivered it. Invoking T. S. Eliot's distinction between the "detachment" necessary for artistic creation and actual "indifference", he had taken the opportunity to comment on Irish nationalists' growing disillusionment with the Anglo-Irish Agreement. This had, at first, seemed to him to imply "an eye-level equilibrium between the British government and the Irish government, an abdication by both sides of the moral high ground, a recognition by Britain that the haughty fiction that the internal affairs of Northern Ireland were a matter of domestic British concern only was indeed a fiction”. Recent events, however, appeared to demonstrate that the British government regarded the Agreement chiefly as a security measure. Commenting on the double standard by which military funerals taking place on the Falls Road were regarded as "a tribal and undesirable form of solidarity", while those in which "the victims were British soldiers" and "the mourners were British parents" were "somehow immunized against tribal significance", Heaney remarked that

The so-called 'spirit of the agreement' is not against the solemnization in public of national sorrows, but it is surely against the gradual obliteration from public British awareness of a realization that policies which Downing Street presumably regard as a hard line against terrorism can feel like a high-handed disregard for the self-respect of the Irish people in general; and it should be against any downplaying of the fact that local Belfast paranoia - generated by a recent graveyard bombing and shooting played some part in the shamefully automatic cruelty and horror of the two British soldiers' deaths which followed. (“Applying”)

Asserting that the "caution rightly induced by detachment has its limits", Heaney recalled instead Irish poet W. B. Yeats's "challenge to the writer ... to hold in a single thought reality and justice" ("Applying"). Some in attendance called "rubbish" after Heaney's comments, an unaccustomed if not unprecedented response to his words ( $\mathrm{O}$ 'Toole).

In an atmosphere in which it took some fortitude for Heaney to align himself publicly with an Irish nationalist position in criticizing British complacency, Father Reid was not wrong to suppose that republicans and constitutional nationalists should be able to identify broad areas of agreement. Nonetheless, the three encounters between Sinn Féin and SDLP representatives in 1988 (the first of which took place just days after the last Gibraltar-related funeral) resembled strained debates more than the exploratory discussions previously conducted by the parties' leaders and gave the participants a clearer sense of their differences than of what they might have in common. Although they agreed in principle on the Irish people's right to "self-determination" and opposed any purely internal solution to Northern Ireland's problems, Sinn Féin equated self-determination with a united Ireland and held to this 
as a firm objective (Adams 77-78). The SDLP, following Hume's reasoning, pointed out that unionists, too, were part of the Irish population and, as such, shared in this right to selfdetermination. Because the British government in the Anglo-Irish Agreement had effectively stated "that Irish unity and independence are entirely a matter for those Irish people who want it persuading those Irish people who don't", it seemed clear to them that "In this context the 'armed struggle' can only be a negative factor" (Durkan 130). Because republicans did not share this view of the British government's neutrality the parties largely talked past each other, but Adams believed the eight months of "detailed debate" had been "important" (Adams 79). In any case, although few knew it at the time, the Hume-Adams dialogue, which now involved the Irish government as well as Father Reid, continued after the SDLP-Sinn Féin talks ended (Durkan 130-131; Adams 80-82).

Heaney had been thinking about doing a version of Sophocles's late play Philoctetes even longer than Hume had been talking with Adams, since at least November $1985 .{ }^{6}$ In true Heaney fashion, though, he hesitated, and he might have gone on considering the prospect indefinitely if not for a postcard from Friel in 1989 imploring him, in terms he could hardly refuse, to contribute a play to Field Day for 1990: "you have got to do something for the theatre - a translation, a version, a dramatization ... You are needed. Okay?" committed himself to writing the play in January 1990 (White). Relying on three English translations because he did not know Greek, Heaney worked "line by line" on his version of the play through the first half of 1990 (O'Driscoll 420-421). Field Day produced it that autumn, touring throughout Ireland with the play during October, November, and early December. ${ }^{8}$

Many in The Cure at Troy's original audiences found the company's decision to produce a classical Greek drama that year puzzling at the time, but Heaney himself saw clear political relevance in its action. He had an advantage over most of Field Day's patrons in knowing quite a bit about Sophocles's original. Works by a number of classical authors, some writing before Sophocles and some after, reveal various aspects of the legends surrounding the Greek archer Philoctetes. Oscar Mandel collates many of these in a chapter on the traditional lore regarding him in his 1981 book Philoctetes and the Fall of Troy, which Heaney likely consulted while working on his version of the play. ${ }^{9}$ In some accounts, Philoctetes had been an Argonaut, serving alongside Hercules in Jason's famous expedition. When, after being poisoned, Hercules decided to die on his own terms, he had asked Philoctetes to light his funeral pyre and bequeathed him, as a reward, his magical bow and arrows; as his body burned, Hercules attained god-like status. The link with Hercules was significant, Mandel points out, because he had led a successful assault on Troy during the reign of the Trojan King Priam's father. Although Hercules died before the Trojan War depicted in the Iliad began, his legendary weapon, wielded by Philoctetes, could have a share in the eventual Greek victory. In all the stories, Philoctetes is bitten by a snake during a stop that the Greek forces make on their way to Troy. The snake-bite is so disabling that Philoctetes is left behind on the island of Lemnos (populated in most versions of the legend) when the Greeks continue on to Troy. In some, though not all, of the stories, his companions abandon Philoctetes because they find the stink of his infected foot and his cries of pain intolerable. In some, but not all, of these accounts, Philoctetes bitterly resents their action. Ten years into the war, the Greeks capture a Trojan soothsayer who informs them that Troy cannot be taken without the assistance of Philoctetes and Neoptolemus (son of the preeminent Greek warrior, Achilles). The two men are brought to Troy, Philoctetes is cured of his wound, and the Greeks go on to win the war. Traditionally, Philoctetes is credited with killing Paris, whose abduction of the Greek hero Menelaus's wife Helen had initiated the conflict, and Neoptolemus with the death of King Priam, father of the Trojan hero Hector who had been killed by his own father (Mandel 3-45). 
In a chapter comparing Sophocles's Philoctetes with earlier plays about him by Aeschylus and Euripides, now lost but doubtless known to Sophocles himself, Mandel highlights Sophocles's distinctive treatment of the traditional material. All three dramas featured Odysseus, the Greek hero most renowned for cunning, as the emissary to Lemnos. All three presented him as having been personally responsible for abandoning Philoctetes there ten years earlier, and all depicted Philoctetes as implacably angry about how he had been treated and dreaming of revenge. Surviving commentaries suggest that, in the Aeschylus and Euripides plays, the drama centred on the question of whether or not Philoctetes would be brought back into the Greek war effort and, if so, how. In these earlier dramatic treatments, Odysseus employed both deceit and theft to obtain the bow. After Philoctetes had been rendered helpless by the loss of his weapon, Odysseus in both versions "persuaded" him to rejoin the Greek forces (Mandel 95-103).

Sophocles's great innovation was to introduce a third major character, Neoptolemus, and to change the stakes of the action, as Mandel explains:

For Aeschylus and Euripides, the question posed by the play had been, 'Will Philoctetes yield to Odysseus?' But Sophocles dropped this question, and decided from the beginning that Philoctetes would not yield to Odysseus or any other mortal. He turned Philoctetes into a fixed and ultimately unproblematic character, and wrote instead a Neoptolemus play dealing with a movement from lie to truth in the mind and action of his new hero. (Mandel 103)

In Philoctetes, Odysseus, with Neoptolemus in tow, arrives on the deserted island of Lemnos determined to obtain the bow belonging to Philoctetes by any means necessary (whether or not he believes Philoctetes himself to be equally indispensable to the Greek cause is a point left notably ambiguous in Sophocles's play). Rather than confront his erstwhile comrade directly, he proposes that Neoptolemus, who was not a member of the original expedition to Troy, should approach Philoctetes, gain his trust by telling his own story of mistreatment at the hands of Odysseus (the Aeschylus and Euripides plays had featured similar tall tales about Odysseus's perfidy), and take the bow when he lets down his guard. Neoptolemus reluctantly agrees, meets Philoctetes, and lies to him along the lines suggested by Odysseus. Instead of seizing the bow, however, he befriends (or pretends to befriend) the outcast, agreeing to take him home in order to trick the older warrior into coming with him of his own accord. Trusting him completely, Philoctetes allows Neoptolemus to hold the bow shortly before being overcome by a paroxysm of pain that pushes him to the limits of his endurance. As he sleeps after this fit, the Chorus urges Neoptolemus to slip away with the bow while he has the chance, but he insists that it will be useless without its owner, that Philoctetes himself must be given his destined share in the Greek victory in order to fulfill the oracle.

When Philoctetes wakes they start walking to the ship, but Neoptolemus, overcome with remorse about deceiving the injured man, feels compelled to tell him the truth about where they are going and why. Philoctetes reacts angrily and refuses to leave, demanding that Neoptolemus return the bow. He is about to do so when Odysseus enters and commandeers it. After an angry confrontation between Philoctetes and Odysseus, the latter orders Neoptolemus back to the ship with him. The Chorus urges Philoctetes to reconsider and come to Troy of his own free will to be healed and win glory, but he remains adamant. Neoptolemus and Odysseus return, and, in direct defiance of his commanding officer, Neoptolemus returns the bow to Philoctetes. When Odysseus leaves to summon the rest of the Greeks to punish the insubordinate youth, Neoptolemus, who has just proved his good will towards Philoctetes, pleads with him one last time to give up his grievance and come with them. The older man still refuses and reminds him of his earlier promise to take Philoctetes 
home, and Neoptolemus agrees to keep it despite his fear of his Greek comrades' retribution. As they prepare to depart, Hercules appears and orders Philoctetes to go to Troy to fulfill his destiny.

The intrusion of the deus ex machina at the end of Sophocles's play comes as a thumping anticlimax. Mandel argues persuasively, however, that the question of whether or not Philoctetes would go to Troy was not the question that interested Sophocles. His play "is a drama of human ethics and politics from which the gods stand aside, if only temporarily", thus

the gods have permitted Neoptolemus just enough objective freedom to make the two authentic moral choices which constitute the play ... Neoptolemus discovers that the most fluent eloquence cannot repair an injustice; justice must be done; it demands action ... For a moment he had thought that returning the life-sustaining bow would do. But Justice is an exacting mistress. Neoptolemus must carry the injured man home: the false invitation must become a true one; and Sophocles underscores its consequences - the Greeks outraged, their cause ruined, a massive revenge threatened. When Neoptolemus makes the second and greater of his decisions, he does so fully conscious that he will become a hounded outcast. His moral victory is complete. (Mandel 110, 112, 113-114)

As in Shakespeare's late romances, tragedy is only narrowly averted by supernatural intervention. The point of the play, for Heaney no less than for Sophocles, lay in the difficult decisions Neoptolemus must make without foreknowledge of their outcome.

Neoptolemus's moral dilemma is what drew Heaney to Sophocles's play, for reasons that, as he explains in an interview with Lorna Hardwick, had everything to do with his Northern Irish upbringing. This had made him precociously aware of "friction between the demands of the group and the demands of the individual integrity":

anyone who grew up in the north of Ireland from their moment of consciousness was aware of ... a public dimension to their lives, they were bonded into a group, one side or the other side. And they were also living in ... the theatre of [their] own conscience and consciousness. So, the demand for solidarity was there from the start with your group, and if you were growing into some kind of authentic individual life, the imperative for solitude or self-respect or integrity or self-definition was there also. (qtd. in Hardwick)

Significantly, Neoptolemus is the only one of the three main characters able fully to acknowledge the legitimacy of both sides of the play's central conflict: that between communal and personal obligations. The dramatic interest resides in watching him move between the fixed poles represented by Odysseus and Philoctetes, who cling tenaciously to their belief in the rightness of their respective positions. Neoptolemus is also the only main character to change significantly in the course of the drama. At the beginning of the play, although he deplores the deceitful methods advocated by Odysseus, he does not doubt that they have a right to deprive Philoctetes of the bow in the cause of winning the war. He even suggests that they should simply overpower the crippled man and take it by force. By the end of the play, he has become, effectively, a traitor to the Greek cause through his unwillingness to lie to Philoctetes.

This does not mean, however, that Neoptolemus thinks Philoctetes is right in refusing to return to the Greek army and help to fulfill the prophecy. Rather, he feels personally bound to keep his promise to the older man and not to take advantage of his trust or force him to come to Troy against his will. On one level, the Cure at Troy can be read as Heaney's defense 
of a liberal political stance that enables one to understand various sides of an issue, whatever one's own opinion about it may be. As Neoptolemus's case demonstrates, this attitude is not without risk. A genuine willingness to listen to different points of view and seek common ground between them can leave one "[d]angerously out between" opposing factions, as Heaney wrote about his friend Sean Armstrong, a social worker killed in 1973 as a result of his activity on both sides of the sectarian divide ("Postcard"). John Hume, in similar fashion, left himself open to charges of double-dealing or worse as he continued to meet secretly with Gerry Adams throughout the period when Heaney was working on his play - at the same time as he was participating in an initiative by Peter Brooke, appointed Secretary of State for Northern Ireland in July 1989, to convene talks involving the four main constitutional parties in the North (the Ulster Unionist Party, the Democratic Unionist Party, the SDLP, and the centrist Alliance Party), the British government, and the Irish government. Brooke's "talks about talks" continued through late 1989 and all of 1990 before actual negotiations got haltingly underway in 1991 (Smith 147-152). Hume's assistant Mark Durkan, one of the few people who knew about both sets of conversations, recalls that Hume regarded them both "as necessary, compatible and potentially complementary" and that he sought to build "layers of understanding in both dialogue channels so that a convergence could be achieved". He walked the tightrope between the two processes via a rigorous commitment to personal honesty, though there was "obviously potential tension in trying to ensure that the SDLP did not adopt language or propositions in either channel that could confound or be seen to contradict understandings in the other" (Durkan 132).

Empathy for people different from oneself is a key ingredient in a liberal mentality. Michael Parker notes that Neoptolemus's "observation first-hand of the excruciating agonies visited on his host" is a "key factor" in his transformation (Parker 16). His witnessing of Philoctetes's suffering awakens his compassion and leads him to attempt to put things right. For Neoptolemus, just action is its own reward, although he understands that it is unlikely to be rewarding in the worldly sense of the word. The only thing that saves the situation, from his perspective, is the reaction his understanding inspires in Philoctetes himself, who, Heaney wrote in a programme note for the Field Day production, "suffers a division in himself between a sense of personal grievance and an inner command (which he keeps repressing) to comprehend his own experience, however painful, in the light of a more generous, less selfcentred vision". At the end of The Cure at Troy, as Heaney explained to a later director of it, the speech of "Hercules" (delivered by the Chorus in Heaney's play) "is an expression of recognition which Philoctetes has repressed: in other words, the Chorus is the voice of his unconscious" ("Production Notes" 173). In positing a psychological alternative to the deus ex machina Heaney followed the example of Edmund Wilson, whose essay on Philoctetes, "The Wound and the Bow", had introduced him to Sophocles's play when he was an undergraduate. Wilson speculates that the god's appearance "may of course figure a change of heart which has taken place in Philoctetes as the result of his having found a man who recognizes the wrong that has been done him and who is willing to champion his cause in defiance of all the Greek forces" (Wilson 283). So the change in Neoptolemus produces a change in Philoctetes, too, although Heaney was aware of the irony that, in surrendering his grievance, "Philoctetes is 'cured' but cured into the very loyalty and solidarity which Neoptolemus had to flout in order to bring the cure about" ("Production Notes" 175).

Thus, Mandel observes, by the end of his play "Sophocles has managed to uphold both the principles of justice and of historical necessity, though they were contradictory up to this point". He agrees, however, with H. D. F. Kitto, who had declared that "nowhere in the whole of Sophocles is there a speech less impressive" than the one he wrote for Hercules. Mandel explains the lapse by stressing that the god's speech was merely a formality to make the action of the play conform with what a classical Greek audience believed to have happened. 
From Sophocles's perspective, "The chief point, that there is something superior to all this, has been made outside [the god's] jurisdiction" (Mandel 115). If Heaney read Mandel's book, one can imagine him finding permission in this passage to try to improve on Sophocles at this point in his own drama.

Heaney took more liberties with the Chorus speeches than with the dialogue passages in The Cure at Troy. The moment at which he decided to use the Chorus to highlight the relevance of the action to contemporary Irish concerns is discernible in Heaney's initial draft of the play. This consists at first of a straight representation, albeit in Northern Irish vernacular speech, of the corresponding dialogue in Philoctetes. About a third of the way through Heaney's first notebook, though, in the middle of a conversation between Neoptolemus and the Chorus about why the apparently innocent Philoctetes has been doomed to such terrible suffering, words start to appear, upside down, on the facing page, as if Heaney had suddenly turned the book over and started scribbling. ${ }^{10}$ This burst of lines contained the germ of what would eventually become Heaney's invented prologue to the action, the Chorus speech that opens The Cure at Troy by reflecting on

People so deep into

Their own self-pity self-pity buoys them up.

People so staunch and true, they're fixated,

Shining with self-regard like polished stones. (1)

Heaney has explained that he saw Philoctetes as "an aspect of every intransigence, republican as well as Unionist, a manifestation of the swank of victimhood, the righteous refusal, the wounded one whose identity has become dependent upon the wound, the betrayed one whose energy and pride is a morbid symptom" ("Production Notes" 175).

Much commentary on Heaney's play, including that of the author himself ("Production Notes" 173-174), has drawn attention to the parallel he establishes in that opening speech between the role of the Chorus and the role of poetry ("the voice / Of reality and justice"), since both operate on the interface

Between

The gods' and human beings' sense of things. (2)

A didactic impulse also prompted Heaney to add the prologue, though, since he knew the play would be performed for audiences who could not be assumed to be familiar with the legends concerning Philoctetes or the conventions of classical Greek drama. Thus his Chorus, after describing people who spend their time "Licking their wounds / And flashing them around like decorations", adds the words

I hate it, I always hated it, and I am

A part of it myself.

And a part of you,

For my part is the chorus, and the chorus

Is more or less a borderline between

The you and the me and the it of it. (2)

Heaney's explicit underlining of the Chorus's function as a representative of the audience on stage acquires increasing significance as the action unfolds, since the Chorus expresses a great deal of uncertainty throughout the play, strongly sympathizing with Philoctetes in his pain and resentment at some points and, at others, encouraging Neoptolemus to follow Odysseus's 
directives and urging Philoctetes to remember that the gods have foreordained that he should fight at Troy. Thus, both Sophocles and Heaney prompt the audience to acknowledge that there is right on both sides.

So what topical resonances might contemporary Northern Irish audiences have seen in the action of the play? Heaney insisted to Barry White that "it is not a political allegory about solutions to the problems of Ireland", adding, "My interest in the play was not in terms of putting a grid of its plot to equal the grid of the forces in the North" (qtd. in White). Nevertheless, he understood that people who attended a Field Day production expected political commentary, however oblique. Hence, Heaney took the further precaution of specifically disavowing readings he considered "entirely wrong". Despite Wilson's use of Philoctetes to illustrate the romantic image of the artist, he categorically denied that he saw himself as "the wounded artist, turning his hurt into something redemptive". He also emphatically rejected "any interpretation that the walled city of Troy equates to Londonderry and that the Greeks are the Catholics and the Trojans the Protestants" and denied that "the taking of Troy is like the taking of the North" (White). The Cure at Troy is certainly not an allegory in the sense of having only one "correct" interpretation, but I concur with Hugh Denard's contention that "Heaney's version often realizes the possibility of polyvalent allegorical alignments" (5). In fact, in attempting to foreclose interpretations he considered obviously mistaken, Heaney sometimes resorted to allegorical readings himself. At a seminar in 1995, for instance, he stated that "Troy would be, not an United Ireland, as such, but an integrated possibility ... a possible future" (Denard 15).

The most obvious political readings of The Cure at Troy centre on Philoctetes as a unionist, with his magic bow representing the so-called unionist veto over constitutional change in Northern Ireland that had historically been underwritten by loyalist paramilitary action as well as by political recalcitrance. Heaney acknowledges that he intended the association, while denying that the character should be interpreted as "a trimly allegorical representation of hardline Unionism" ("Production Notes" 175). Self-exiled to the political wilderness since their vehement rejection of the Anglo-Irish Agreement in November 1985, unionists had defied the predictions of people like John Hume who had believed that the accord between the British and Irish governments would provoke a "catharsis within unionism [that] would lead to a necessary adjustment to not having all power in its own hands" (Durkan 125). Instead, for the ensuing five years, unionists had clung to a futile resistance and to slogans including "Ulster Says No!" and "No Surrender!".

From the opening speech of The Cure at Troy, when the Chorus uses the word "staunch" (often paired with "unionist" in Northern Irish political discourse) to describe people smothered in self-pity, Heaney draws parallels between this mindset and Philoctetes's festering grievance. Audiences hearing Philoctetes denounce the Greek commanders - "Gods curse them all! / I ask for the retribution I deserve. / I solemnly beseech the gods to strike / The sons of Atreus in retaliation" (19) - might well have been reminded of the DUP leader Ian Paisley's equally theatrical appeal to his God to "deal with" British Prime Minister Margaret Thatcher shortly after she signed the hated Agreement: "O God, in wrath take vengeance upon this wicked, treacherous lying woman; take vengeance upon her, Oh Lord, and grant that we shall see a demonstration of thy power" (Bew and Gillespie 189). Philoctetes's plaintive remarks about Lemnos - "a home where I never was at home" (29), "The island's all there is / That'll stand to me" (51) - recall the passionate attachment to the physical landscape of Ireland that, for many unionists, can coexist with their denial of any cultural affiliation. His outraged reaction to the Chorus's suggestion that, deep down, he wants to come to Troy takes the form of a compact metaphor for the famed "siege mentality" of Ulster Protestants: "Never. No. No matter how I'm besieged. / I'll be my own Troy. The Greeks will never take me" (63). When Neoptolemus asks him pointblank, "Are you going to 
stay here saying no for ever / Or do you come in with us?", Philoctetes resolutely rebuffs him before coming back with a question of his own: "What sort of a surrender do you want?" (69). Nathan Wallace observes that such echoes of "unionist rhetoric" were amplified in the Field Day production by the fact that Des McAleer, who played Philoctetes, "growled and hollered his lines so that they sounded like Paisley". Indeed, "some in Field Day started to call the play 'Ulcer Says No"' (118).

Readings of Heaney's Philoctetes as a hardline unionist sometimes assume that Odysseus and Neoptolemus must represent nationalists or republicans and interpret the play as a symbolic representation of reconciliation between Catholics/nationalists and Protestants/unionists in Northern Ireland. This approach, however, misses the element of betrayal that Heaney regarded as central to the drama (White). Philoctetes's grudge is not against a traditional enemy, but against former allies. As Parker observes, his pus-filled wound is not his only agony: "the callousness and injustice of fellow-countrymen acts as an additional, gnawing source of pain" (3). A more precise analogy might associate Odysseus with Thatcher and Neoptolemus with Brooke, who, mere months into his tenure as Northern Ireland Secretary, in November 1989, had stated publicly his belief that it was not possible to defeat the IRA by military means and that the British government "would need to be imaginative" if the "terrorists were to decide the moment had come when they wished to withdraw from their activities" (qtd. in Parker 6).

Brooke's remarks had an inflammatory effect on unionist opinion, but he got more positive attention from the Sinn Féin leadership (Adams 92). Hume had so far been disappointed in his hope that the Anglo-Irish Agreement would promote a new reasonableness on the unionist side, but he had always given "equal significance to the agreement's potential to refute the residual rationale for armed struggle" (Durkan 125). His ongoing discussions with Adams would have reinforced his sense of possible change at this time. Heaney's comment to Denard that Philoctetes's position could "suit a Sinn Féiner" (4) indicates that he, too, was alert to damaging division on the nationalist side and mindful of the contemporary effort to forge a pan-nationalist consensus on ends and means that would preclude the threat or use of force - the magic bow of militant republicans. In this scenario, Odysseus might represent the Irish government (also involved in the secret negotiations) which had, from the republican point of view, marooned Northern Catholics in a repressive Protestant statelet at the time of partition, while Hume himself fits into the mediating role of Neoptolemus.

In this context, Hume's developing personal relationship with Adams acquires a significance akin to that between Neoptolemus and Philoctetes in the play, and it is worth remembering that Hume's empathy was the quality Heaney chose to emphasize in a November 1969 essay about his friend: "What other politician has Hume's attentive intelligence and sympathy for his opponent?" (“John Hume's Derry"). Adams, who understood that "We were more the 'enemy' than the British and the unionists for some of the SDLP leadership", appreciated that Hume risked his reputation and even his safety by continuing to meet and talk with him (Adams 79). He suspected that Hume often kept his own party colleagues in the dark and "got the distinct impression at different times that there were efforts from within his party hierarchy to restrict John's room to manoeuvre" (Adams 80). Like Neoptolemus, Hume sometimes acted in ways that seemed contrary to his own party's interests in pursuit of what he regarded as higher aims, and political scientist Cathy GormleyHeenan writes that "hindsight has shown that Hume's sustained and successful attempts at engaging Adams in the [peace] process were undertaken at the expense of the SDLP's electoral successes in later years" (197). Hume himself likely understood and accepted that this would be the case; this was, after all, a man said to have told colleagues who disagreed with his tactics that "If it's a choice between the party and peace, do you think I give a fuck for the party?" (O Connor 24). 
Heaney departs most decisively from the Sophoclean text at the end of The Cure at Troy, adding an original long speech before the lines attributed to Hercules. In a classical Greek production of the play, performed by three actors in masks, the actor playing Odysseus would also have played Hercules. ${ }^{11}$ At least as significant as Heaney's interpolation of lines of his own devising at this juncture is the fact that he assigns them, as well as the Hercules speech, to the Chorus (played in the Field Day production by a trio of women), so that the attitudes expressed seem to emanate directly from the consciousness of the audience. After vacillating during the drama itself, the Chorus finally speaks out with conviction, exhorting both the characters on stage and the audience in the theatre to

\author{
... hope for a great sea-change \\ On the far side of revenge. \\ Believe that a further shore \\ Is reachable from here. \\ Believe in miracles \\ And cures and healing wells. (77)
}

Eileen Battersby reported in the Irish Times before The Cure at Troy's first performance that Heaney "would be impatient with the idea that there is a coded message about Northern Ireland contained in the play or any inference that the play is an analogy for how the troubles could be resolved", quoting him as saying, "I'm not a political writer and I don't see literature as a way of solving political problems ... I don't think any miracle is going to happen in the North" (Battersby). Though reviewers such as Michael Coveney of the Observer seized on this Chorus speech as "Heaney's first overtly political statement", the poet himself was quick to observe that "The Chorus's sense of suffering is absolutely true, I think. No song or poem, they say, will ever right a wrong inflicted and endured. The rest ... isn't politics. It's sentiment" (Walsh).

As sentiment, though, the Chorus's climactic speech staked its claim to the particular kind of efficacy that Heaney believed literature could have in the world. As early as 1972, he had stated that he did not subscribe to the view that "poetry makes nothing happen": "It can eventually make new feelings, or feelings about feelings, happen, and anybody can see that in this country for a long time to come a refinement of feelings will be more urgent than a reframing of policies or of constitutions" (Richtarik 6). This speech expressed less a political position than a disposition: to focus on the future rather than the past, to believe that something better is possible. In the words of Heaney's friend and fellow Field Day board member Seamus Deane,

The turn in his poetry that is matched by The Cure at Troy is not simply a turn from ground to air; it is a turn from place to time, from a past that was literally grounded ... to a mobile future ... This is not a preordained destiny into which the past, history, snugly fits. It is a future the past could not imagine when it was embedded in its apparently inescapable stereotypes. (Deane 19)

Heaney described The Cure at Troy as "a kind of 'post-cease-fire' writing avant la lettre" ("Production Notes" 178), although he acknowledged that the uplifting attitudes expressed by his Chorus remained "in the realm of pious aspiration" (O'Driscoll 421). The very title of Heaney's play points beyond the frame of the drama: the desirable future that Philoctetes finally decides to set his sights on, the end of his physical pain, the end of the Trojan War. "For utopia to be conceivable at all", Terry Eagleton writes, "it must ... be somewhere prefigurable in the flesh-and-blood of the present, in the shape of an instinctive creaturely 
response to another's needs. But the fullest realisation of this humanity is equally, ineluctably deferred to the just city of the future, which only political practice can bring about" (Eagleton 174). The vision Heaney presents at the end of The Cure at Troy seemed utopian in 1990, but it would be realized to an extent that no one then could have predicted before the end of the decade.

\section{Notes}

${ }^{1}$ Alan Peacock, for example, discusses The Cure at Troy as a key step in Heaney's development of a public poetic voice; Hugh Denard examines the play as a post-colonial text that also critiques contemporary postcolonial discourse; Aidan O'Malley analyzes it in the context of Field Day's mission, conceived as a translation project; Richard Rankin Russell relates the play to the entire body of Heaney's work through analysis of intertextual references to the writings of W. B. Yeats and Wilfred Owen; and Michael Parker offers a detailed and convincing reading of Heaney's drama with special attention to those places where Heaney does most to "colonize" Sophocles's text. All of these analyses reward study. The author is also indebted to Matt Bolch, Paula Hawkins, Michael Parker, and the anonymous peer reviewers for Estudios Irlandeses for their helpful comments on a draft of this article, and she wishes to thank the Seamus Heaney and Brian Friel estates for permission to quote from unpublished letters.

${ }^{2}$ See, for example, Denard (1-2), O'Malley (120), and Parker (5). Adams's book about the peace process, published in Europe as Hope and History: Making Peace in Ireland and in the United States as A Farther Shore: Ireland's Long Road to Peace (the latter title is a slight misquotation of a late Chorus speech in Heaney's play), also contained an epigraph consisting of lines from The Cure at Troy.

${ }^{3}$ Seamus Heaney, letter to Brian Friel, 22 January 1988, National Library of Ireland, Dublin, MS 37, 102/1.

${ }^{4}$ It should be noted that Adams describes his first meeting with Hume as taking place considerably earlier than others who have chronicled the peace process would put it. Mark Durkan, for example, places Father Reid's initial approach in "early 1987" (126), and Hume asserted in 1996 that his "direct communication" with Adams "began with a letter I wrote to him on St. Patrick's Day in 1988" (115) despite the fact that a private meeting between the two men was widely reported in the press in January 1988 and denied by neither. However, a recent book about Father Reid's peace ministry by a fellow Redemptorist priest includes the text of Reid's first letter to Hume, dated 19 May 1986 (McKeever 112-129). Since various accounts agree that Hume's response to Reid was both prompt and positive, I find Adams's narrative most plausible and speculate that the discrepancy with other versions of the story stems from the fact that their earliest meetings were held in secret, with information about them withheld even from Hume's closest SDLP colleagues.

${ }^{5}$ See Dennis O'Driscoll's Stepping Stones: Interviews with Seamus Heaney for Heaney's account of his relationship with Hume, which dated back to their days as pupils at St. Columb's College in Derry, and their mutual friendship with Friel (176-177).

${ }^{6}$ Minutes of the Field Day board meeting, 9-10 November 1985, Stuart A. Rose Manuscript, Archives, and Rare Book Library, Emory University, Atlanta, Georgia, MS 880, box 52, file folder 1.

${ }^{7}$ Brian Friel, letter to Seamus Heaney, [1 May] 1989, Rose Library, MS 960, b39/ff9. The underline appears in the original text.

${ }^{8}$ Flyer from the original Field Day production of Seamus Heaney's The Cure at Troy (1990), collection of the author.

${ }^{9}$ I have no evidence to prove that Heaney read Mandel's book. However, Harvard's Widener Library owned a copy, and it would be strange if Heaney (an anxious first-time playwright as well as a scrupulous scholar) did not at least peruse it.

${ }^{10}$ Seamus Heaney, draft of The Cure at Troy, National Library of Ireland, MS 49, 493/233, Notebook 1. The first draft of the Chorus speech appears opposite a page dated 3 February 1990.

${ }^{11}$ In tragedies, the use of one actor was standard until Aeschylus added a second; later, Sophocles revised the form by adding a third actor (Jacobus 36 ).

\section{Works Cited}

Adams, Gerry. Hope and History: Making Peace in Ireland. London: Brandon, 2003. Bardon, Jonathan. A History of Ulster. Belfast: Blackstaff, 1992. Battersby, Eileen. "Sometimes a Great Notion”. Irish Times. 29 September 1990. 
Bew, Paul and Gordon Gillespie. Northern Ireland: A Chronology of the Troubles 1968-1993. Dublin: Gill \& Macmillan, 1993.

Coveney, Michael. Review of The Cure at Troy, by Seamus Heaney. Observer. 7 October 1990.

Deane, Seamus. “Oranges and Lemnos". New Statesman \& Society (5 April 1991): 18-19.

Denard, Hugh. "Seamus Heaney, Colonialism, and the Cure: Sophoclean Re-Visions". PAJ: A Journal of Performance and Art 22.3 (September 2000): 1-18.

Durkan, Mark. "Shaping the Peace". John Hume: Irish Peacemaker. Ed. Seán Farren and Denis Haughey. Dublin: Four Courts, 2015. 120-142.

Eagleton, Terry. "Unionism and Utopia: Seamus Heaney's The Cure at Troy". Theatre Stuff: Critical Essays on Contemporary Irish Theatre. Ed. Eamonn Jordan. Dublin: Carysfort, 2000. 172-175.

Gormley-Heenan, Cathy. "Political Leader". John Hume: Irish Peacemaker. Ed. Seán Farren and Denis Haughey. Dublin: Four Courts, 2015. 193-202.

Hardwick, Lorna. Interview with Seamus Heaney. 2007. 15 October 2017. www.open.ac.uk/arts/research/pvcrs/sites/www.open.ac.uk.arts.research.pvcrs/files/fil es/Heaney_transcript_PDF(1).pdf

Heaney, Seamus. "Applying the Yeats Challenge to the Anglo-Irish Agreement". Boston Globe. 27 June 1988.

. The Cure at Troy. London: Faber, 1990.

. "The Cure at Troy: Production Notes in No Particular Order". Amid Our Troubles: Irish Versions of Greek Tragedy. Ed. Marianne McDonald and J. Michael Walton. London: Methuen, 2002. 171-180. “John Hume's Derry". Hibernia. 21 November 1969. 7.

. "A Postcard from North Antrim.” Field Work. New York: Noonday, 1979. 19-20.

Hume, John. A New Ireland: Politics, Peace and Reconciliation. Foreword by Senator Edward M. Kennedy. Introduction by Tom McEnery. Edited by Jack Van Zandt and Tom McEnery. Boulder, Colorado: Roberts Rinehart, 1996.

Jacobus, Lee A., ed. The Bedford Introduction to Drama, $2^{\text {nd }}$ ed. Boston: Bedford/St. Martin's, 1993.

Mandel, Oscar. Philoctetes and the Fall of Troy: Plays, Documents, Iconography, Interpretations. Lincoln and London: University of Nebraska Press, 1981.

McKeever, Martin. One Man, One God: The Peace Ministry of Fr Alec Reid C.Ss.R. Dublin: Redemptorist Communications, 2017.

O Connor, Fionnuala. Breaking the Bonds: Making Peace in Northern Ireland. Edinburgh: Mainstream, 2002.

O’Driscoll, Dennis. Stepping Stones: Interviews with Seamus Heaney. New York: Farrar, Straus and Giroux, 2008.

O'Malley, Aidan. Field Day and the Translation of Irish Identities: Performing Contradictions. Basingstoke: Palgrave Macmillan, 2011.

O'Toole, Fintan. "Seamus Heaney: Beyond the Normal Niceties". Colour Tribune. 10 April 1988.

Parker, Michael. "Back in the Republic of Conscience: Seamus Heaney's The Cure at Troy, Its Politics, Ethics, and Aesthetics". Textual Practice (2016). 9 March 2016. http://dx.doi.org/10.1080/0950236X.2015.1119985

Peacock, Alan. "Mediations: Poet as Translator, Poet as Seer". Seamus Heaney: A Collection of Critical Essays. Ed. Elmer Andrews. New York: St. Martin's, 1992. 233-255.

Richtarik, Marilynn. Acting Between the Lines: The Field Day Theatre Company and Irish Cultural Politics 1980-1984. Oxford: Oxford University Press, 1994. 
Russell, Richard Rankin. Seamus Heaney's Regions. Notre Dame: University of Notre Dame Press, 2014.

Smith, Jeremy. Making the Peace in Ireland. London: Longman, 2002.

Wallace, Nathan. Hellenism and Reconciliation in Ireland from Yeats to Field Day. Cork: Cork University Press, 2015.

Walsh, John. "Bard of Hope and Harp". Sunday Times. 7 October 1990.

White, Barry. "'Troy' is the Setting for Heaney's First Play". Belfast Telegraph. 29 September 1990.

Wilson, Edmund. The Wound and the Bow: Seven Studies in Literature. Cambridge: Houghton Mifflin, 1941.

Received: 2 November 2017 Revised version accepted: 12 February 2018

Marilynn Richtarik is a Professor of English at Georgia State University in Atlanta. Her books include Acting Between the Lines: The Field Day Theatre Company and Irish Cultural Politics 1980-1984 (Oxford University Press, 1994), Stewart Parker: A Life (Oxford University Press, 2012), and an edition of Parker's autobiographical novel Hopdance (The Lilliput Press, 2017). She spent the spring semester of 2017 as a US Fulbright Scholar at Queen's University Belfast, teaching a class and working on a book about literary reactions and contributions to the peace process in Northern Ireland.

mrichtarik@gsu.edu 